\title{
Effects of intravenous insulin-like growth factor-I and insulin administration on insulin-like growth factor-binding proteins in the ovine fetus
}

\author{
W-H Shen, X Yang, D W Boyle, W H Lee and E A Liechty \\ Herman B Wells Center for Pediatric Research, Indiana University School of Medicine, 699 West Drive, Indianapolis, Indiana 46202, USA \\ (Requests for offprints should be addressed to E A Liechty, Riley Hospital R-208, 699 West Drive, Indianapolis, Indiana 46202, USA; Email: eliecht@iupui.edu)
}

\begin{abstract}
The insulin-like growth factors (IGF) are important anabolic hormones in the mammalian fetus; their anabolic actions are potentially modulated by alterations in the IGF-binding proteins (IGFBP). We have previously shown that the nutritional state of the fetus affects both IGF-I and the IGFBP concentrations. The present study was designed to determine the effect of alterations in insulin and IGF-I circulating concentrations on the IGFBPs. Because both insulin and IGF-I elicit decreases in glucose and amino acid concentrations, the concentrations of these substrates were clamped during the hormone infusions.

Sixteen ovine fetuses were chronically catheterized at approximately 115 days of gestation, and experimental procedures performed at approximately 130 days of gestation. Insulin, IGF-I or both were infused for an 8-h period. Baseline concentrations of hormones and binding proteins were obtained, and concentrations were also
\end{abstract}

obtained at the end of the infusion. Hepatic IGFBP-1 mRNA expression was also determined.

Intravenous infusion of IGF-I significantly increased IGF-I concentrations in plasma in the ovine fetus. Intravenous infusion of insulin inhibited hepatic IGFBP-1 gene expression when amino acids and glucose were clamped. In contrast, intravenous infusion of recombinant human IGF-I (rhIGF-I) enhanced hepatic IGFBP-1 gene expression. Neither insulin nor rhIGF-I treatment had an effect on hepatic IGFBP-3 gene expression. Insulin did not alter plasma IGFBP-1 significantly, but it increased IGFBP-3 in plasma. rhIGF-I increased both IGFBP-1 and IGFBP-3 protein levels in plasma.

The responses of IGFBP-1 and IGFBP-3 to increased plasma IGF-I and insulin may serve to protect the fetus from exaggerated anabolic effects and to blunt the hypoglycemic potential of circulating IGFs and insulin.

Journal of Endocrinology (2001) 171, 143-151

\section{Introduction}

Insulin has long been considered an important fetal metabolic hormone (Susa et al. 1984), and several extensive studies of insulin regulation of fetal glucose and protein metabolism have been performed (Hay \& Meznarich 1986, Liechty et al. 1992). In addition, insulin-like growth factor (IGF)-I and IGF-II are potent metabolic, mitogenic and differentiative factors, and considered to be important regulators of fetal growth (D'Ercole 1991, Iwamoto et al. 1992, Liechty et al. 1996). IGF-I is widely expressed in fetal tissues (Han et al. 1987, Rotwein et al. 1987). The circulating concentration of IGF-I has been shown to correlate directly with fetal weight in humans and decreased concentrations of IGF-I have been found in association with fetal growth retardation (Lassarre et al. 1991, Owens et al. 1994). Deletion of the IGF-I gene in mice results in high mortality, reduced birth weight and retarded rate of postnatal growth (Liu et al. 1993). Anabolic effects of short-term IGF-I infusion have been demonstrated in the ovine fetus (Liechty et al. 1996).
Almost all IGFs in the circulation and extravascular fluids (except saliva) are complexed to a class of proteins called IGF-binding proteins (IGFBPs), which bind IGF-I and IGF-II with an affinity equal to or greater than that of IGF receptors (D’Ercole 1991, Drop et al. 1991). So far, six species of IGFBPs have been purified, and their cDNAs cloned and characterized (Shimasaki \& Ling 1991, Swisshelm et al. 1995). Although the functions of IGFBPs are not fully understood, the circulating IGFBPs have the potential to influence the bio-potency of circulating IGFs by their ability to bind IGFs. In addition, the presence of a cell membrane integrin-binding region (RGD sequence) in some binding-protein species (IGFBP-1 and IGFBP-2) suggests that the binding proteins have a capacity to associate with the cell surface.

There is less information regarding the IGF-IGFBP interaction in the fetus. It has been demonstrated that IGFBP-1, -2, -3 and -4 are expressed in various fetal tissues at high levels and their expression declines after birth (Orlowski et al. 1990, Osborn et al. 1992, Carr 
et al. 1995, Currie et al. 1996). IGFBP-1, $-2,-3$ and -4 have been found in the fetal circulation, and the levels are affected by nutritional status (McLellan et al. 1992, Osborn et al. 1992, Lee et al. 1997). IGFBP-1 immunoreactivity has been found in every fetal tissue except the brain, spleen and thyroid (Hill et al. 1989b). In addition, the birth weight of the growth-retarded infant is inversely related to maternal serum levels of placental protein-12 (IGFBP-1) (Howell et al. 1985). Higher liver IGFBP-1 mRNA abundance and serum IGFBP-1 levels are found to be associated with fetal growth retardation (Straus et al. 1991). More recently, reduced fetal survival and fetal growth retardation have been seen in transgenic animals with high IGFBP-1 expression (Gay et al. 1997). These observations strongly suggest that IGFBP may play a role in regulating fetal growth by binding to IGFs. Better knowledge of the IGF-IGFBP interactions and IGFBP regulation is vital to understanding the physiological actions and importance of IGFs in the fetus.

Our previous study has shown that the nutritional state of the fetus affects both IGF-I and the IGFBP concentrations (Lee et al. 1997). The purpose of the present study was to examine the responses of IGFBPs to IGF-I and insulin infusion in the ovine fetus. By infusing each hormone singly and in combination, we were able to discern the unique and interactive effects of each hormone on the IGFBP hepatic mRNA expression and circulating protein in fetal plasma. Because both insulin and IGF-I elicit decreases in glucose and amino acid concentrations (Liechty et al. 1992, 1996), the concentrations of these substrates were clamped during the hormone infusions in order to evaluate the response of IGFBPs to the hormone infusion, independent of nutrient supplies.

\section{Materials and Methods}

Animals and surgical procedures

Sixteen ewes of 115-120 days of gestation were utilized for this study. Animal care was in strict compliance with National Institutes of Health guidelines within an Association for Assessment and Accreditation of Laboratory Animal Care (AAALAC) certified facility, and the Institutional Animal Care and Use Committee approved the study protocols.

Surgical procedures were performed aseptically under general anesthesia. Anesthesia was induced with intravenous ketamine and maintained with isoflurane inhalation. Fetal catheters were placed in the inferior vena cava, common umbilical vein and abdominal aorta. Catheters were exteriorized and irrigated daily with $0.9 \%$ saline containing $50 \mathrm{U}$ heparin $/ \mathrm{ml}$. All ewes consumed ad libitum a diet consisting of hay and pelletized alfalfa and had constant access to water and salt lick.
Study design

The animals were allowed a minimum of 6 days of recovery from operative stress before study. Complete recovery was assessed by monitoring maternal food intake, fetal and maternal glucose concentrations and acid-base status. The animals were fed ad libitum before and throughout the study.

On the day of the study, baseline blood samples were obtained. Then, the fetus was infused with one of the following four infusates: (A) saline, (B) insulin (890 $\mathrm{mIU} / \mathrm{h}$ ), (C) recombinant human (rh) IGF-I (gift of Eli Lilly Research Laboratories, Indianapolis, IN, USA) plus a replacement dosage of insulin (40 nmol IGF-I/h and 16 $\mathrm{mIU}$ insulin/h) and (D) rhIGF-I and insulin (40 nmol IGF-I/h and $890 \mathrm{mIU}$ insulin/h). The dose of insulin infused in study $\mathrm{C}$ was expected to maintain plasma insulin concentrations at the baseline level, counteracting the inhibition of insulin secretion during the rhIGF-I infusion. During infusion, the fetal whole blood glucose was clamped at the baseline level by a variable infusion of $20 \%$ glucose that was titrated by frequent arterial glucose sampling, with the goal of maintaining the glucose concentration constant. Throughout the study, the total fetal plasma branched chain amino acid (BCAA) concentrations were measured at a 15-min interval and a balanced amino acid solution (AminoSyn II; Abbott Laboratories, Abbott Park, IL, USA) was infused at a variable rate to maintain plasma BCAA at the baseline level (Wray-Cahen et al. 1998). Eight hours following initiation of infusion, blood samples were collected from the fetal aorta for measurement of IGFBPs, IGF-I and insulin, and the fetus was autopsied. A liver sample was collected and snap-frozen in liquid nitrogen, and stored at $-70{ }^{\circ} \mathrm{C}$ before extraction for total RNA.

\section{Hormone and chemical assays}

Total branched chain amino acid concentrations were monitored by spectrophotometry during IGF-I and insulin infusion (Wray-Cahen et al. 1998). The actual leucine concentrations in plasma and whole blood were measured by an automated amino acid analyzer (Beckman 6300; Beckman-Coulter, Palo Alto, CA, USA). The fetal whole blood glucose was monitored with a glucose analyzer (YSI 2300; Yellow Springs Instruments, Yellow Springs, OH, USA).

Insulin concentrations in plasma were determined in duplicate by a double antibody radioimmunoassay (RIA). Total IGF-I in plasma was determined by validated competitive RIA that employed formic acid-acetone as the IGF-I extraction procedure (Liechty et al. 1996, Lee et al. 1997).

\section{Western ligand blot}

Ovine plasma samples $(2 \mu \mathrm{l})$ were subjected to nonreduced discontinuous SDS-PAGE on a $4 \cdot 0 \%$ stacking gel 
and $12 \%$ polyacrylamide separating gel for $1.5 \mathrm{~h}$ at $100 \mathrm{~V}$. The proteins were transferred onto a polyvinylidene difluoride (PVDF) membrane with a BioRad transfer unit at $100 \mathrm{~V}$ for $90 \mathrm{~min}$, and blocked with blocking buffer I (10 mM Tris, $150 \mathrm{mM} \mathrm{NaCl}, 0 \cdot 05 \% \mathrm{Na}$ Azide, $0 \cdot 1 \%$ bovine serum albumin (BSA), 3\% Nonidet P-40, pH 7.5) for $30 \mathrm{~min}$. Next, the membrane was blocked with blocking buffer II $(10 \mathrm{mM}$ Tris, $150 \mathrm{mM} \mathrm{NaCl}, 0 \cdot 05 \% \mathrm{Na}$ Azide, $0 \cdot 1 \%$ BSA and $0 \cdot 1 \%$ Tween-20, $\mathrm{pH} 7 \cdot 5$ ) for $2 \mathrm{~h}$ and then rinsed with RIA buffer. The membrane was incubated with $1 \mu \mathrm{Ci}{ }^{125}$ I IGF-II in $10 \mathrm{ml}$ RIA buffer at $4{ }^{\circ} \mathrm{C}$ overnight. The membrane was then washed in RIA buffer and air-dried before being exposed to a phophor screen (Molecular Dynamics, Sunnyvale, CA, USA) at room temperature overnight. Areas of specific binding were detected, and the relative changes in binding proteins were assessed by densitometric analysis (Molecular Dynamics).

\section{Western immunoblot for IGFBP-1 and RIA for IGFBP-2}

A synthetic ovine IGFBP-1 fragment was used as an antigen, and a polyclonal antibody was generated in rabbits (Shen et al. 2000). IGFBP-1 Western immunoblots were performed as follows. Plasma $(1 \cdot 2 \mu \mathrm{l})$ was separated on a $12.5 \%$ reducing SDS-PAGE and transferred to PVDF membranes. Membranes were blocked in 5\% non-fat milk in $0.01 \mathrm{M}$ phosphate-buffered saline containing $0.1 \%$ Tween-20 overnight at $4{ }^{\circ} \mathrm{C}$, then incubated with a rabbit anti-ovine IGFBP-1 antibody in the blocking buffer (dilution 1:5000) at room temperature for $1 \mathrm{~h}$. The membranes were washed, incubated with horseradish peroxidase-conjugated goat anti-rabbit IgG (dilution 1:1500) (Amersham Pharmacia Biotech, Piscataway, NJ, USA). Detection was performed using enhanced chemiluminescence (ECL) reagents from Amersham Pharmacia Biotech. Films were scanned and images were quantitated by Scion image software (Scion Co., Frederick, MD, USA).

Plasma IGFBP-2 concentrations were also measured by an IGFBP-2 RIA kit (DSL-7100; Diagnostic Systems Laboratories, Inc., Webster, TX, USA). The antibodies in this kit have been found to cross-react with sheep IGFBP-2.

\section{Northern hybridization}

An ovine IGFBP-1 probe of $400 \mathrm{bp}$ was generated by RT-PCR using primer (5'-GGAATTCGAGATAACT CAGGAGCAG-3', 5'-GCCCGCTCGAGTCAGTTCT GTAAGTTAAAATA-3'). The sequence was confirmed by its high homology (96\%) with bovine IGFBP-1 (Sneyers et al. 1991). Ovine IGFBP-3 probe of 372 bp was also generated by RT-PCR. The primers used were based on the partial sequence of ovine IGFBP-3 kindly provided by Peter Hastie, University of Wales, Aberystwyth, Wales, UK.
Total RNA $(15 \mu \mathrm{g})$ extracted from the ovine fetal liver was electrophoresed on a $1.0 \%$ agarose-formaldehyde gel at $100 \mathrm{~V}$ for $2-3 \mathrm{~h}$. Separated RNA was transferred to a Magna nylon transfer membrane (Micron Separations Inc., Westboro, MA, USA) by capillary blotting, and crosslinked to the membrane by exposure to UV light. The membrane was prehybridized and then probed with a ${ }^{32} \mathrm{P}$ cDNA probe of $400 \mathrm{bp}$ encoding the $\mathrm{C}$ terminal of ovine IGFBP-1, or a probe encoding ovine IGFBP-3, at $65^{\circ} \mathrm{C}$ for $3 \mathrm{~h}$. After washing and air-drying, the membrane was exposed to X-ray film at $-70{ }^{\circ} \mathrm{C}$ for 3-6 days and analyzed using scanning densitometry (Molecular Dynamics). Signals are expressed as an arbitrary unit above the background for each autoradiograph and adjusted for RNA sample loading differences by expressing each message as a ratio of the glyceraldehyde phosphate dehydrogenase (GAPDH) message.

\section{Statistical analysis}

All values are expressed as meansts.E.M. Data were analyzed by analysis of variance for repeated measurements (JMP; SAS Inc, Cary, NC, USA). Differences between pre- and post-infusion were analyzed by paired Student's $t$-test. The levels of significance of differences were as indicated.

\section{Results}

\section{Whole blood glucose and plasma leucine concentration}

The fetal weights, glucose concentrations, leucine concentrations and IGF-II concentrations are given in Table 1. There were no significant differences between the groups in fetal weights. Mean glucose and leucine concentrations were greater in the rhIGF-I group. Also given in Table 1 are the plasma concentrations of insulin. There were significant differences between the groups that corresponded to infusion of pharmacologic insulin. There was no significant difference in insulin concentration between the control group and the IGF-I infusion group, which received insulin at a replacement dosage to counteract the effect of IGF-I on insulin inhibition.

The fetal blood glucose concentrations and leucine concentrations were kept constant during hormone infusion by the clamp technique (data not shown). There were no significant within-group differences in leucine or glucose concentrations during studies.

\section{Plasma IGF-I concentrations}

Following an 8-h intravenous IGF-I administration, plasma total IGF-I increased from 82 to $410 \mathrm{ng} / \mathrm{ml}$ $(P<0 \cdot 01)$ (Fig. 1). Insulin infusion had no effects on plasma IGF-I levels. 
Table 1 Mean concentrations of hormones and substrates during the four experimental conditions. Concentrations were calculated as the mean of four samples 20 min apart, taken during the final $80 \mathrm{~min}$ of the 8 -h infusion period. Fetal weights were obtained at autopsy immediately following the 8 -h infusion. Values are means \pm S.E.M.; $n=4$ in each group

\begin{tabular}{|c|c|c|c|c|}
\hline & Control & rhIGF-I & Insulin & Both \\
\hline Fetal weight (kg) & $2 \cdot 88 \pm 0 \cdot 26$ & $3 \cdot 13 \pm 0 \cdot 66$ & $3.95 \pm 0.55$ & $3 \cdot 2 \pm 0 \cdot 66$ \\
\hline Glucose (mg/dl) & $14 \cdot 1 \pm 5 \cdot 9$ & $18 \cdot 2 \pm 7 \cdot 72$ & $13 \cdot 5 \pm 2 \cdot 86$ & $14 \cdot 4 \pm 3.91$ \\
\hline Leucine $(\mu \mathrm{M})$ & $120 \pm 7 \cdot 4$ & $153 \pm 7 \cdot 3$ & $145 \pm 11$ & $134 \pm 6 \cdot 8$ \\
\hline Insulin $(\mu \mathrm{U} / \mathrm{ml})$ & $16 \cdot 8 \pm 12$ & $41 \cdot 6 \pm 29 \cdot 5$ & $332 \pm 217$ & $350 \pm 71 \cdot 3$ \\
\hline IGF-I (ng/ml) & $151 \pm 36$ & $402 \pm 36$ & $122 \pm 36$ & $410 \pm 41$ \\
\hline IGF-II (ng/ml) & $655 \pm 57$ & $741 \pm 57$ & $729 \pm 57$ & $754 \pm 60$ \\
\hline
\end{tabular}

${ }^{*}$ Mean is significantly different, $P<0 \cdot 05$, by one-way ANOVA and Fisher's least significant difference test.

Effects of insulin and IGF-I on plasma IGFBPs

In all animals, we identified four protein species with the capacity to bind ${ }^{125}$ I IGF-II by the Western ligand blot (Fig. 2). Judged by the molecular weights, the four binding proteins are IGFBP-3 (a doublet, 36-41 kDa), IGFBP-2 $(28 \cdot 5 \mathrm{kDa})$, IGFBP-1 (25 kDa) and IGFBP-4 (22 kDa)

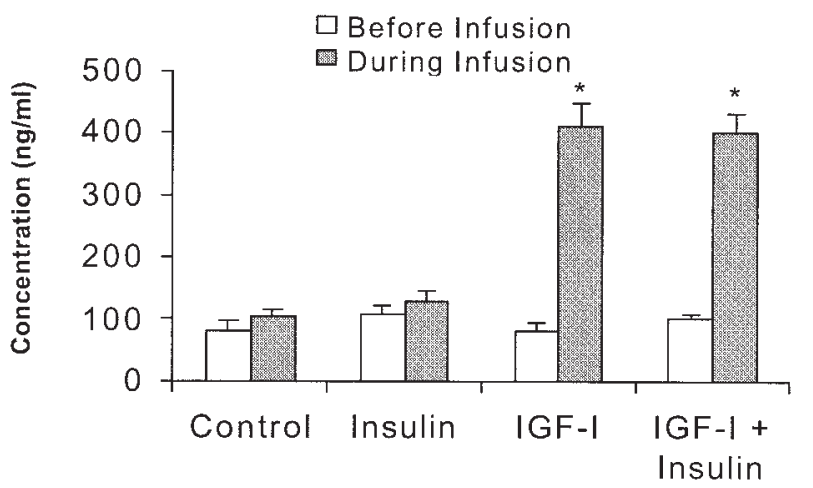

Figure 1 Total IGF-I concentrations in the fetal circulation $(\mathrm{ng} / \mathrm{ml})$ before (open bars) and after (shaded bars) infusion of saline (control), insulin, IGF-I or IGF-I plus insulin (IGF-I+Insulin) for $8 \mathrm{~h}$. Each value represents the mean \pm S.E.M. ${ }^{*} P<0 \cdot 01$ : levels are significantly different before and after infusion.

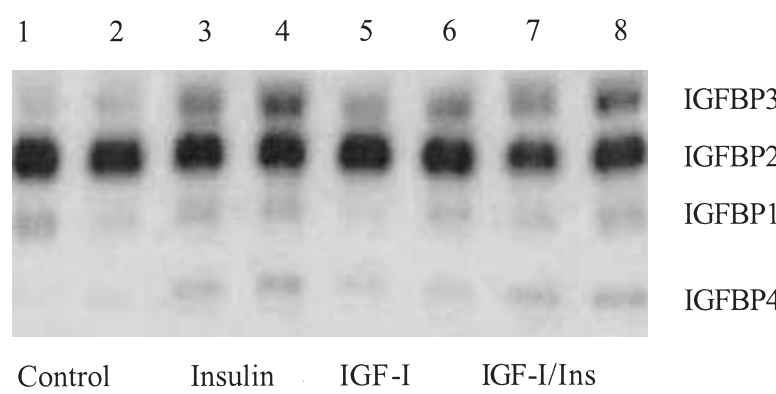

Figure 2 Western ligand blot analysis of plasma IGFBPs. A representative autoradiograph is shown to demonstrate the changes in plasma IGFBPs before (lanes 1, 3, 5 and 7) and after (lanes 2, 4, 6 and 8) infusion, showing relative densities of IGFBP-1, IGFBP-2, IGFBP-3 and IGFBP-4 from pooled samples of each group (Control, Insulin, IGF-I and IGF-I/Ins). respectively (Lee et al. 1997). Infusion of IGF-I led to an increase in plasma IGFBP-1 and IGFBP-3 concentrations $(P<0 \cdot 05)$ (Fig. 3). After intravenous administration of IGF-I, IGFBP-1 and IGFBP-3 were elevated each by $30 \%$. Insulin infusion had no effects on plasma IGFBP-1, but increased plasma IGFBP-3 significantly $(P<0 \cdot 05)$. Fetal plasma IGFBP-2 and IGFBP-4 were not affected by insulin and IGF-I infusion.

Since the IGFBP-1 blot in the Western ligand blots may also contain other proteins such as IGFBP-5, IGFBP-6, glycosylated IGFBP-4 and IGFBP-3 fragments, IGFBP-1 might be overestimated in this method. In order to distinguish IGFBP-1 from other proteins with the same electrophoretic migration rate on SDS-polyacrylamide gels, we performed IGFBP-1 Western immunoblotting using a specific polyclonal antibody. The results showed that the polyclonal antibody recognized a specific band with a molecular weight of $32 \mathrm{kDa}$, which is consistent

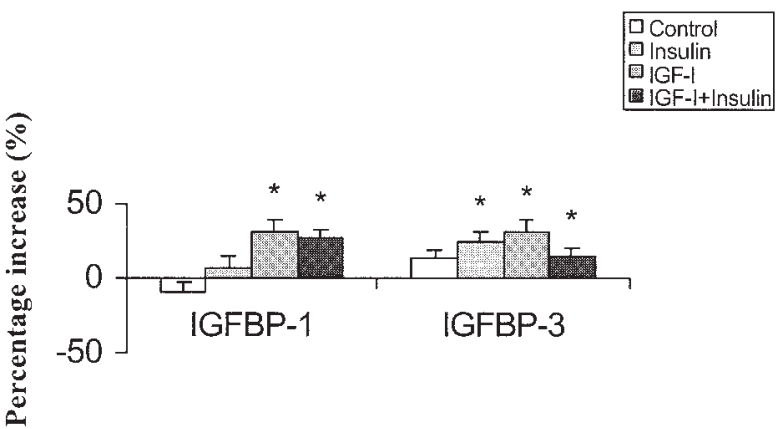

Figure 3 Percentage increases of IGFBP-1 and IGFBP-3 during IGF-I and insulin infusion. IGFBPs were measured by Western ligand blot as described in Materials and Methods. The percentage increases or decreases were calculated by the difference between basal (before infusion) and at the end of the 8-h infusion, divided by the basal IGFBP level. The value (increase percentage) represents the mean \pm S.E.M. ${ }^{*} P<0 \cdot 01$ : levels are significantly different before and after infusion. 


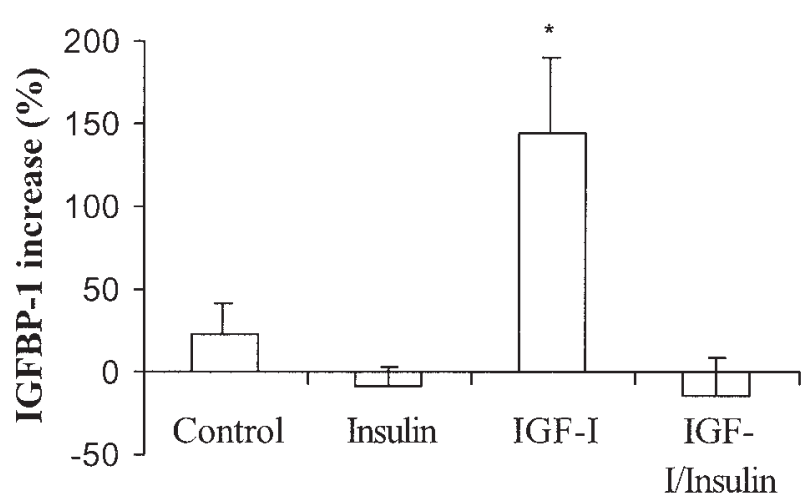

Figure 4 Alterations in plasma IGFBP-1 after intravenous infusion of insulin, IGF-I or both. Plasma IGFBP-1 was determined by protein immunoblot after SDS-PAGE separation. The percentage increases or decreases of IGFBP-1 were calculated by the blot density difference between basal and after the 8-h infusion, divided by the basal IGFBP level. Results are means \pm S.E.M. for four fetuses in each group. ${ }^{*} P<0 \cdot 01$ : levels are significantly different from the control group by Student's $t$-test.

with ovine IGFBP-1 (Fig. 4). Densitometry analysis revealed similar results to those from the Western ligand blot. IGF-I infusion increased plasma IGFBP-1 significantly $(P<0 \cdot 05)$. In contrast, insulin and insulin plus IGF-I decreased IGFBP-1 by $9 \%$ and $13 \%$ respectively, but these alternations in plasma IGFBP-1 following insulin or insulin plus IGF-I treatment were not significantly different from that of the control.

Consistent with that from the Western ligand, plasma IGFBP-2 measured by RIA was not significantly changed after insulin and IGF-I infusion, with an average concentration of $2300 \mathrm{ng} / \mathrm{ml}$.

\section{Effects of insulin and IGF-I on IGFBP-1 and IGFBP-3 gene expression}

Northern blot hybridization identified an mRNA transcript encoding IGFBP-1 with a size of $1.6 \mathrm{~kb}$, and an mRNA transcript encoding IGFBP-3 with a size of $2 \cdot 4-2 \cdot 6 \mathrm{~kb}$. The relative expressions of IGFBP-1 and IGFBP-3 mRNA were quantified after adjusting for the differences in RNA loading by analysis of GAPDH expression and therefore represented true differences in signal intensity. Densitometric analysis indicated that the IGFBP-1 expression level decreased by $82 \%$ after insulin infusion, compared with the control (saline infusion) (Figs 5 and 6). In contrast, infusion of IGF-I increased IGFBP-1 gene expression levels in the ovine liver by $248 \%$. When insulin and IGF-I were co-administered, the IGFBP-1 expression level decreased by 64\% (IGF-I plus insulin group). In contrast, IGF-I and insulin infusion showed no effects on hepatic IGFBP-3 expression in the ovine fetus.

\section{Discussion}

The factors controlling the synthesis and degradation of the IGFBPs are poorly understood in the fetus. We have previously demonstrated that the fetal circulating IGFBP-1 increased significantly following a 5-day maternal fast (Lee et al. 1997). In addition, IGF-I infusion into the fetal circulation resulted in an overall increase in fetal circulating IGFBPs (Lee et al. 1997). However, in that study, both insulin and amino acid concentrations decreased significantly during IGF-I infusion. It is therefore difficult to assess the contribution of substrate availability and hormone status in the regulation of fetal circulating IGFBPs. In the present study, the fall in amino acid and glucose concentrations was prevented during IGF-I and insulin infusion by infusing variable amounts of glucose and a balanced amino acid solution. In addition, a replacement dose of insulin was co-administered with IGF-I in study $\mathrm{C}$ to counteract the inhibition of insulin secretion during the IGF-I infusion. By using this amino acid/glucose/insulin clamp technique, we were able to evaluate the contribution of individual hormones in regulating the fetal circulating IGFBP. Under these conditions, intravenous infusion of insulin was found to significantly reduce hepatic IGFBP-1 gene expression in the ovine fetus (Fig. 5), implying that insulin has a direct effect on IGFBP-1 expression in the fetus. Our findings are consistent with those early studies in which a reverse relation between the circulating insulin and hepatic IGFBP-1 mRNA was reported in the fetal sheep (Osborn et al. 1992, Hooper et al. 1994).

In the current study, no significant changes were detected at the IGFBP-1 protein level in plasma $8 \mathrm{~h}$ after insulin infusion although there was a tendency for insulin to decrease plasma IGFBP-1 (Fig. 4). The non-parallel change of plasma IGFBP-1 and hepatic IGFBP-1 gene expression after insulin infusion suggests that the hepatic mRNA expression is only one of the factors which contribute to plasma IGFBP-1 during insulin infusion. It seems that insulin may exert effects on IGFBP-1 secretion and/or degradation as well as on hepatic IGFBP-1 gene expression. In addition, although liver is believed to be a primary source of fetal circulating IGFBP-1 (Pannier et al. 1994), changes in the production of IGFBP-1 in tissues other than liver may also contribute to the changes in fetal plasma IGFBP-1. It has been reported that IGFBP-1 mRNA is expressed in other fetal tissues, such as kidney (McLellan et al. 1992, Pannier et al. 1994). Finally, placental and/or maternal IGFBP-1 could contribute to IGFBP-1 in the fetal circulation.

Intravenous infusion of IGF-I into the ovine fetus at a dose of $10 \mathrm{nmol} / \mathrm{kg}$ per h resulted in a significant increase in fetal plasma IGF-I and IGFBP-1 $(P<0 \cdot 05)$ (Figs 1 and 4). Northern analysis showed that IGF-I enhanced hepatic IGFBP-1 mRNA level significantly (Fig. 5). This finding 


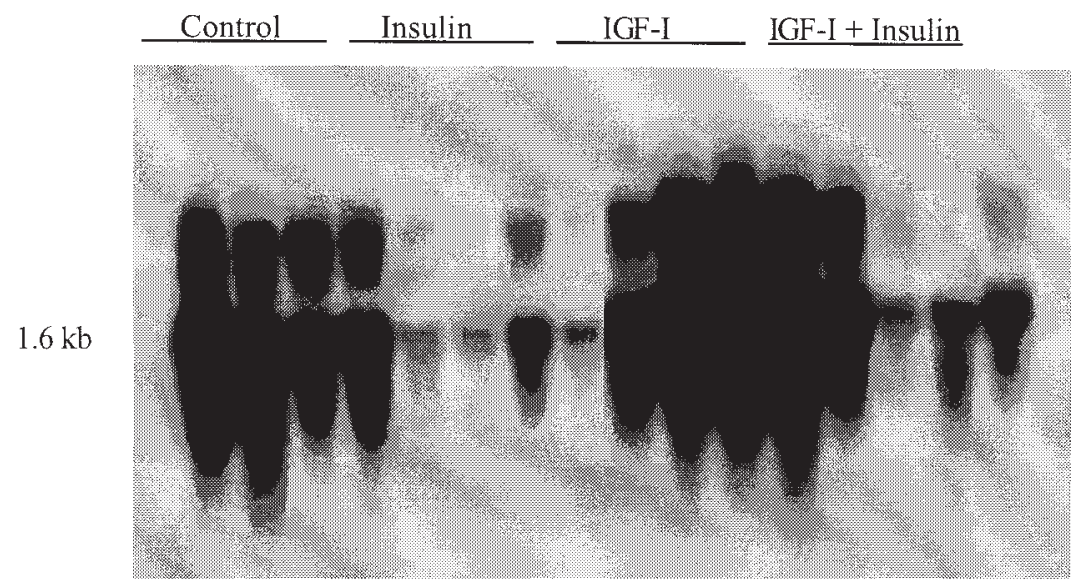

IGFBP-1

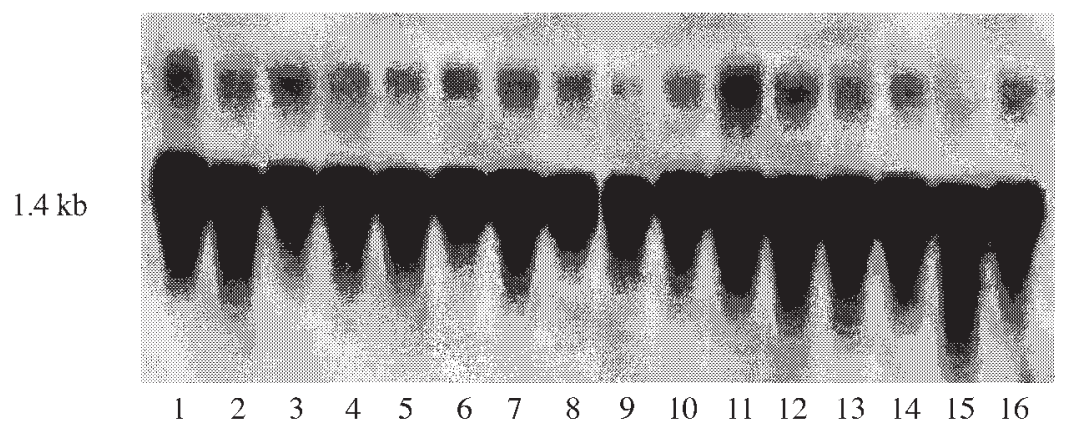

GAPDH

Figure 5 Northern blot analyses showing hybridization of ${ }^{32}$ P-labeled probes to mRNA transcripts encoding sheep IGFBP-1 (upper panel) and GAPDH (lower panel). Total RNA was prepared from the fetal liver of four animals from the control (lanes 1-4), insulin (lanes 5-8), IGF-I (lanes 9-12) and IGF-I plus insulin groups (lanes 13-16).

implies that the increased plasma IGFBP-1 level following IGF-I infusion may be, in part, due to enhanced IGFBP-1 expression level, and the regulatory effects of IGF-I on

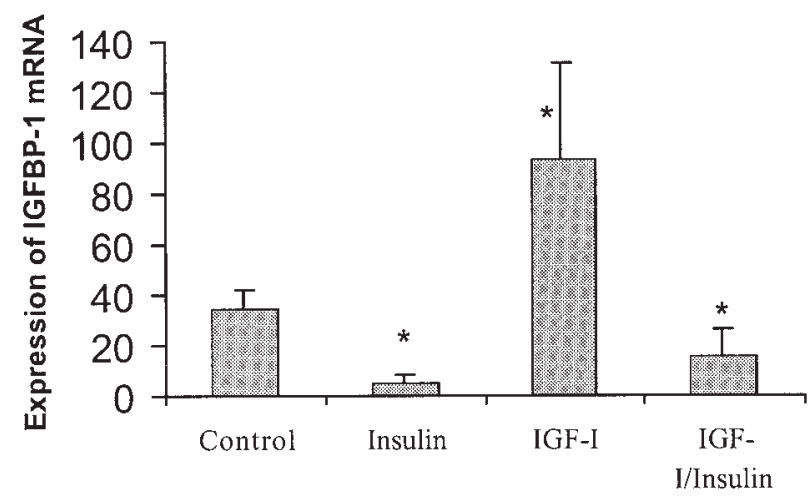

Figure 6 IGFBP-1 expression in the ovine fetal liver after infusion of saline, insulin, IGF-I and IGF-I plus insulin for $8 \mathrm{~h}$. Values (means \pm S.E.M.) are corrected for loading by comparison with expression of mRNA encoding GAPDH. ${ }^{*} P<0 \cdot 01$ : levels are significantly different from the control group.
IGFBP-1 were partially mediated at the transcriptional level. The present findings are consistent with previous studies from our group, but the amino acid clamp was not performed in the previous studies (Lee et al. 1997). The up-regulation of IGFBP-1 by IGF-I has also been demonstrated in vitro in human fetal fibroblasts (Hill et al. 1989a), and this response mimics that found in adult humans (Zapf et al. 1990, Baxter et al. 1993, Russell-Jones et al. 1997).

The mechanism by which IGFBP-1 levels were increased by the IGF-I infusion in vivo remains unclear. The decreased insulin level after IGF-I administration has been considered to be responsible for increased IGFBP-1 production. However, this explanation cannot account for the findings in the current study since insulin was kept constant during the IGF-I infusion (Table 1). Actually, the insulin levels in the IGF-I group were slightly higher than, although not statistically different from, those in the control. Our findings indicate that IGF-I itself may have direct regulatory effects on IGFBP-1 as well as indirectly enhancing IGFBP-1 by inhibiting insulin secretion. 
The combination of IGF-I and insulin (the IGF-I plus insulin group) decreased hepatic IGFBP-1 gene expression level $(P<0 \cdot 05)$ (Fig. 6), but did not change the IGFBP-1 protein level significantly (Fig. 4). This may imply that the IGF-I stimulation of IGFBP-1 gene expression is less potent than insulin suppression on IGFBP-1 gene expression.

The present study showed that, following intravenous infusions of insulin, the IGFBP-3 levels in plasma increased significantly in the ovine fetus $(P<0 \cdot 05)$ (Fig. 3). However, IGFBP-3 gene expression was not significantly changed (data not shown). In this regard, our results are in contrast to those of Villafuerte et al. (1996), who reported that hepatic IGFBP-3 expression was stimulated directly by provision of insulin in co-cultured liver cells of normal rats. However, they also found that accumulation of IGFBP-3 in conditioned medium was higher than changes in IGFBP-3 mRNA, suggesting post-translational modulation of IGFBP-3 of insulin (Villafuerte et al. 1996). It is not known why insulin did not stimulate IGFBP-3 gene expression in our current study, but insulin dose could be one of the factors which determine its stimulation potency. The insulin in the circulation in the present study is only $1 / 600$ of that of Villafuerte et al. (1996).

It has also been well established that IGF-I inhibits insulin secretion in vitro (Guler et al. 1989a) and in vivo (Liechty et al. 1996). As discussed above, insulin has the potential to stimulate IGFBP-3 production. To determine how IGF-I alone modulates IGFBP-3 production, we investigated the effects of IGF-I infusion on plasma IGFBP-3 after clamping insulin. Under this condition, IGF-I infusion led to a significant increase of plasma IGFBP-3 $(P<0.05)$ (Fig. 5). This response was similar to that in postnatal life. When insulin was kept constant by infusion of growth hormone, IGF-I infusion increased the circulating IGFBP-3 levels (Kupfer et al. 1993). However, treatment with IGF-I alone led to a decrease in plasma IGFBP-3, probably due to decreased insulin levels, a potent enhancer of IGFBP-3, following IGF-I administration. The relative concentrations of insulin and IGF-I in plasma could be one of the reasons why the conflicting results were obtained among early studies regarding this issue. Responses of IGFBP-3 to IGF-I likely reflect a dynamic balance between stimulation by IGF-I, insulin and other hormones/metabolic factors.

IGF-I infusion did not alter hepatic IGFBP-3 expression in the present study. This apparent discrepancy between the gene expression and the circulating protein levels indicates that, like insulin, IGF-I may regulate plasma IGFBP-3 at the post-transcriptional level. Nevertheless, IGF-I and insulin may have different posttranslational mechanisms in regulating IGFBP-3. IGF-I might increase the stability of IGFBP-3 at the peptide levels in the circulation through the $150 \mathrm{kDa}$ complex formation with the acid-labile subunit (Baxter \& Martin 1989).
Why IGF-I exhibits effects on IGFBP-1 and IGFBP-3, but not on IGFBP-2 and IGFBP-4, is still unknown. So far, six members of the IGFBP gene family have been identified and cognate cDNAs from a variety of species have been cloned. Although all the IGFBPs share approximately 50\% homology, they are derived from separate genes and show different regulation and tissue-specific expression (Rechler 1993). Of the IGFBPs that have been shown to be present in the circulation, IGFBP-3 appears to be responsible for the majority of the IGF-binding capacity present in the adult plasma (Baxter \& Martin 1989). Also, it has been shown that, due to formation of the $150 \mathrm{kDa}$ IGFBP-3 complex, IGFs bound to IGFBP-3 have a longer half-life than those bound to other IGFBPs present in the circulation (Guler et al. 1989b). The role of IGFBP-3 in prenatal life is less clear. Although circulating IGFBP-3 is lower in the fetus than that in adult, suggesting a minor role of IGFBP-3 in the fetus (D'Ercole 1991), there is a study demonstrating that IGFBP-3 mRNA abundance in the fetal liver is greater than that in maternal liver (Currie et al. 1996). IGFBP-1 has a lower concentration in the serum, and the affinity for IGFs is lower than that of IGFBP-3. However, it is largely unsaturated and is widely regulated by a variety of hormones and nutrient supplies (Rechler 1993, Lee et al. 1997). This may, in part, explain why IGFBP-1 and IGFBP-3 exhibit more instantaneous changes than other IGFBPs during IGF-I and/or insulin infusion. There is less information about IGFBP-2 and IGFBP-4 and their functions in the fetus are not clearly understood. In the present study, we have confirmed that the majority of IGFBPs is IGFBP-2 in the ovine fetal circulation (Fig. 2). While this suggests a specific role of IGFBP-2 in the fetus, the circulating IGFBP-2 shows no response to insulin and IGF-I infusion. In addition, the gene knockout experiments of IGFBP-2 had no major phenotypic effects (Pintar et al. 1994).

In summary, using an amino acid/glucose/insulin clamp technique ensuring adequate metabolic substrate supply and constant insulin concentration, we have shown, for the first time, that intravenous infusion of IGF-I into the ovine fetus at a dose of $40 \mathrm{nmol} / \mathrm{h}$ increases IGFBP-1 and IGFBP-3 levels in the plasma, and the up-regulation of IGFBP-1 by IGF-I occurs, in part, at the gene expression level. After clamping glucose and amino acid concentrations, intravenous infusion of insulin increases plasma IGFBP-3 levels, but depresses IGFBP-1 gene expression in the ovine liver. The non-parallel changes in plasma IGFBPs protein and hepatic mRNA expression suggest multiple regulation mechanisms of IGFBP by the hormones. The responses of IGFBP-1 and IGFBP-3 to suddenly increased plasma IGF-I and insulin may serve to protect the fetus from exaggerated anabolic effects and to blunt the hypoglycemic potential of circulating IGFs and insulin. 


\section{References}

Baxter RC \& Martin JL 1989 Structure of the Mr 140,000 growth hormone-dependent insulin-like growth factor binding protein complex: determination by reconstitution and affinity labeling. PNAS 86 6898-6902.

Baxter RC, Hizuka N, Takano K, Holman SR \& Asakawa K 1993 Responses of insulin-like growth factor binding protein-1 (IGFBP-1) and the IGFBP-3 complex to administration of insulin-like growth factor-I. Acta Endocrinologica 28 101-108.

Carr JM, Owens JA, Grant PA, Walton PE, Owens PC \& Wallace JC 1995 Circulating insulin-like growth factors (IGFs), IGF-binding proteins (IGFBPs) and tissue mRNA levels of IGFBP-2 and IGFBP-4 in the ovine fetus. Journal of Endocrinology 145 545-557.

Currie MJ, Bassett NS, Breier BH, Klempt M, Min SH, Mackenzie DDS, McCutcheon SN \& Gluckman PD 1996 Differential effects of maternal ovine placental lactogen and growth hormone (GH) administration on $\mathrm{GH}$ receptor, insulin-like growth factor (IGF)-1 and IGF binding protein-3 gene expression in the pregnant and fetal sheep. Growth Regulation 6 123-129.

D'Ercole AJ 1991 The insulin-like growth factors and fetal growth. In Modern Concepts of Insulin-like Growth Factors. Ed EM Spencer. New York: Elsevier Science Publishing Co. Inc.

Drop S, Brinkman A, Kortleve D, Groffen C, Schuller A \& Zqarthoff E 1991 The evolution of the insulin-like growth factor binding protein family. In Modern Concepts of Insulin-like Growth Factors, pp 311-328. Ed EM Spencer. New York: Elsevier Science Publishing Co. Inc

Gay E, Seurin D, Babajko S, Doublier S, Cazillis M \& Binoux M 1997 Liver-specific expression of human insulin-like growth factor binding protein 1 in transgenic mice: repercussions on reproduction, ante-, and perinatal mortality and postnatal growth. Endocrinology 138 2937-2947.

Guler HP, Schmid C, Zapf J \& Froesch ER 1989a Effects of recombinant insulin-like growth factor I on insulin secretion and renal function in normal human subjects. PNAS $\mathbf{8 6}$ $2868-2872$.

Guler HP, Zapf J, Schmid C \& Froesch ER 1989b Insulin-like growth factors I and II in healthy man. Estimations of half-lives and production rates. Acta Endocrinologica 121 753-758.

Han VKM, D'Ercole AJ \& Lund PK 1987 Cellular localization of somatomedin (insulin-like growth factor) messenger RNA in the human fetus. Science 236 193-197.

Hay WWJ \& Meznarich H 1986 The effect of hyperinsulinemia on glucose utilization and oxidation and on oxygen consumption in the fetal lamb. Quarterly Journal of Experimental Physiology 71 689-698

Hill DJ, Camacho-Hubner C, Rashid P, Strain AJ \& Clemmons DR $1989 a$ Insulin-like growth factor (IGF)-binding protein release by human fetal fibroblasts: dependency on cell density and IGF peptides. Journal of Endocrinology 122 87-98.

Hill DJ, Clemmons DR, Wilson S, Han VKM, Strain AJ \& Milner RDG 19896 Immunological distribution of one form of insulin-like growth factor (IGF)-binding protein and IGF peptides in human fetal tissues. Journal of Molecular Endocrinology 2 31-38.

Hooper SB, Bocking AD, White SE, Fraher LJ, McDonald TJ \& Han VKM 1994 Catecholamines stimulate the synthesis and release of insulin-like growth factor binding protein-1 (IGFBP-1) by fetal sheep liver in vivo. Endocrinology 134 1104-1112.

Howell RJ, Perry LA, Choglay NS, Bohn H \& Chard T 1985 Placental protein 12 (pp12): a new test for the prediction of the small-for-gestational age infant. British Journal of Obstetrics and Gynaecology 92 1141-1144.

Iwamoto HS, Murray MA \& Chernausek SD 1992 Effects of acute hypoxemia on insulin-like growth factors and their binding proteins in fetal sheep. American Journal of Physiology: Endocrinology and Metabolism 263 E1151-E1156.

Kupfer SR, Underwood LE, Baxter RC \& Clemmons DR 1993 Enhancement of the anabolic effects of growth hormone and insulin-like growth factor I by use of both agents simultaneously. Journal of Clinical Investigation 91 391-396.

Lassarre C, Hardouin S \& Daffos F 1991 Serum insulin-like growth factors and insulin-like growth factor binding proteins in the human fetus. Relationships with growth in normal subjects and in subjects with intrauterine growth retardation. Pediatric Research 29 219-225.

Lee WH, Gaylord TD, Bowsher RR, Hlaing M, Moorehead H \& Liechty EA 1997 Nutritional regulation of circulating insulin-like growth factors (IGFs) and their binding proteins in the ovine fetus. Endocrine Journal 44 163-173.

Liechty EA, Boyle DW, Moorehead H, Liu YM \& Denne SC 1992 Effect of hyperinsulinemia on ovine fetal leucine kinetics during prolonged maternal fasting. American Journal of Physiology: Endocrinology and Metabolism 263 E696-E702.

Liechty EA, Boyle DW, Moorehead H, Lee WH, Bowsher RR \& Denne SC 1996 Effects of circulating IGF-I on glucose and amino acid kinetics in the ovine fetus. American Journal of Physiology: Endocrinology and Metabolism 271 E177-E185.

Liu JP, Baker J, Perkins AS, Robertson EJ \& Efstratiadis A 1993 Mice carrying null mutations of the genes encoding insulin-like growth factor I (Igf-1) and type 1 IGF receptor (Igf1r). Cell $\mathbf{7 5}$ 59-72.

McLellan KC, Hooper SB, Bocking AD, Delhanty PJD, Phillips ID, Hill DJ \& Han VKM 1992 Prolonged hypoxia induced by the reduction of maternal uterine blood flow alters insulin-like growth factor-binding protein-1 (IGFBP-1) and IGFBP-2 gene expression in the ovine fetus. Endocrinology 131 1619-1628.

Orlowski CC, Brown A, Ooi GT, Yang YW-H, Tseng LY-H \& Rechler MM 1990 Tissue, developmental, and metabolic regulation of messenger ribonucleic acid encoding a rat insulin-like growth factor-binding protein. Endocrinology 126 644-652.

Osborn BH, Fowlkes J, Han VKM \& Freemark M 1992 Nutritional regulation of insulin-like growth factor-binding protein gene expression in the ovine fetus and pregnant ewe. Endocrinology 131 1743-1750.

Owens JA, Kind KL, Carbone F, Robinson JS \& Owens PC 1994 Circulating insulin-like growth factor-I and -II and substrates in fetal sheep following restriction of placental growth. Journal of Endocrinology 140 5-13.

Pannier EM, Irwin JC \& Giudice LC 1994 Insulin-like growth factor binding proteins in human fetus: tissue specific protein secretion, immunologic characterization, and gene expression. American Journal of Obstetrics and Gynecology 171 746-752.

Pintar JE, Green BN, Grewal A, Cerro JA \& Wood TL 1994 Analysis of IGFBP-2 function: lessons from gene targeting. Growth Regulation 4 S16.

Rechler MM 1993 Insulin-like growth factor binding proteins. In Vitamins and Hormones, vol. 47, pp 1-114. Eds GD Aurbach \& DB McCormick. New York: Academic Press.

Rotwein P, Pollock KM, Watson M \& Milbrandt JD 1987 Insulinlike growth factor gene expression during rat embryonic development. Endocrinology 121 2141-2144.

Russell-Jones DL, Umpleby AM, Shojaee-Moradie F, Boroujerdi MA, Jones RH, Baxter RC \& Sonksen PH 1997 The effect of an intravenous infusion of IGF-I and insulin on IGFBP-1, IGFBP-3, acid labile subunit, free and bound IGF-I, catecholamines and potassium in normal volunteers during an amino acid and glucose clamp. Clinical Endocrinology 47 685-691.

Shen WH, Yang X \& Liechty EA 2000 Cloning of cDNA encoding sheep IGFBP-1 and generation of a fusion protein for monoclonal antibody producition. FASEB Journal 14 A89.

Shimasaki S \& Ling N 1991 Identification and molecular characterization of insulin-like growth factor binding proteins 
(IGFBP-1, -2, -3, -4, -5 and -6). Progress in Growth Factor Research 3 243-66.

Sneyers M, Kettmann R, Massart S, Renaville R, Burny A \& Portetelle D 1991 Cloning and characterization of a cDNA encoding the bovine insulin-like growth factor binding protein 1 (bIGFBP-1). DNA Sequence 1 407-408.

Straus DS, Ooi GT, Orlowski CC \& Rechler MM 1991 Expression of the genes for insulin-like growth factor-I (IGF-I), IGF-II, and IGF-binding proteins-1 and -2 in fetal rat under conditions of intrauterine growth retardation caused by maternal fasting. Endocrinology 127 1849-1856.

Susa JB, Neave C, Sehgal P, Singer DB, Zeller WP \& Schwartz R 1984 Chronic hyperinsulinemia in the fetal rhesus monkey. Effects of physiologic hyperinsulinemia on fetal growth and composition. Diabetes 33 656-660.

Swisshelm K, Ryan K, Tsuchiya K \& Sager R 1995 Enhanced expression of an insulin-like growth factor-like binding protein (mac25) in senescent human mammary epithelial cells and induced expression with retinoic acid. PNAS 92 4472-4476.
Villafuerte BC, Zhang WN \& Phillips LS 1996 Insulin and insulinlike growth factor-I regulate hepatic insulin-like growth factor binding protein-3 by different mechanisms. Molecular Endocrinology 10 622-630.

Wray-Cahen D, Nguyen HV, Burrin DG, Beckett PR, Fiorotto ML, Reeds PJ, Wester TJ \& Davis TA 1998 Response of skeletal muscle protein synthesis to insulin in suckling pigs decreases with development. American Journal of Physiology: Endocrinology and Metabolism 275 E602-E609.

Zapf J, Schmid C, Guler HP, Waldvogel M, Hauri C, Futo E, Hossenlopp P, Binoux M \& Froesch ER 1990 Regulation of binding proteins for insulin-like growth factors (IGF) in humans. Increased expression of IGF binding protein 2 during IGF I treatment of healthy adults and in patients with extrapancreatic tumor hypoglycemia. Journal of Clinical Investigation 86 952-961.

Received 5 June 2001

Accepted 26 June 2001 